American Journal of Environmental Sciences 4 (4): 310-315, 2008

ISSN 1553-345X

(C) 2008 Science Publications

\title{
Environmental Performance of the Milling Process Of Malaysian Palm Oil Using The Life Cycle Assessment Approach
}

\author{
${ }^{1}$ Vijaya Subramaniam, ${ }^{1}$ Ma An Ngan, ${ }^{1}$ Choo Yuen May and ${ }^{2}$ Nik Meriam Nik Sulaiman \\ ${ }^{1}$ Engineering and Processing Division, Malaysian Palm Oil Board, \\ No. 6 Persiaran Institusi Bandar Baru Bangi, 43000 Kajang, Selangor, Malaysia \\ ${ }^{2}$ Department of Chemical Engineering, University of Malaya, 50603 Kuala Lumpur, Malaysia
}

\begin{abstract}
Malaysia is currently the world leader in the production and export of palm oil. This study has a gate to gate system boundary. The inventory data collection starts at the oil palm fresh fruit bunch hoppers when the fresh fruit bunch is received at the mill up till the production of the crude palm oil in the storage tanks at the mill. The plantation phase and land use for the production of oil palm fresh fruit bunch is not included in this system boundary. This gate to gate case study of 12 mills identifies the potential impacts associated with the production of palm oil using the life cycle assessment approach and evaluates opportunities to overcome the potential impacts. Most of the impact categories show savings rather than impact. Within the system boundary there are only two main parameters that are causing the potential impacts to the environment; they are the Palm Oil Mill Effluent (POME) followed by the boiler ash. The impact categories that the POME contributes to are under the Respiratory Organics and Climate Change. Both these impact categories are related to air emissions. The main air emission from the POME ponds during the anaerobic digestion is the biogas which consists of methane, carbon dioxide and traces of hydrogen sulfide. An alternate scenario was conducted to see how the impact will be if the biogas was harvested and used as energy and the results shows that when the biogas is harvested, the impact from the POME is removed. The other significant impact is the boiler ash. This is the ash that is produced when the biomass is burnt in the boiler. This potential impact contributes to the ecotoxicity impact category. This is mainly because of the disposal of this ash which in most cases was used for land application in the roads leading to the mil or in the plantations. If the parameters causing these two potential impacts are curbed, then this will be a further plus point for the Malaysian oil palm industry which is already avoiding fossil fuel based energy and chemical use for processing.
\end{abstract}

Key words: Life cycle assessment, life cycle impact assessment, biomass, palm oil, palm oil mill

\section{INTRODUCTION}

Malaysia is one of the world leaders in the production and export of palm oil. The total exports of oil palm products, constituting of palm oil, palm kernel oil, palm kernel cake, oleo chemicals and finished products reached 20.13 million tons in 2006 from 18.62 million tons recorded in $2005^{[4]}$. Exports of palm oil alone reached a commendable 14.40 million tons 2006 from 13.45 million tons in $2005^{[4]}$. China, maintained its position as the largest export market or Malaysian palm oil for the fifth consecutive year followed by the European Union , Pakistan, USA, India , Japan and Bangladesh. Together these seven countries accounted for 9.32 million tons or $64.7 \%$ of total Malaysian palm oil exports in $2006^{[4]}$. The oil palm industry is an export orientated industry which heavily relies on the world market. Therefore it is very vital for the oil palm industry to be sustainable and competitive to increase its long-term profitability and sustainability. The western countries are known for their high environmental standards. Since European Union is the second largest importer of palm oil, it is essential that the oil palm industry is ready to meet the higher expectation of these overseas customers on the environmental performance of the industry. These environmental performance expectations can slowly begin to transform into demands in the market place and may even become a market barrier in the future ${ }^{[5]}$. In view of this it would be wise to introspect,

Corresponding Author: Vijaya Subramaniam, Engineering and Processing Division, Malaysian Palm Oil Board,

No.6 Persiaran Institusi Bandar Baru Bangi, 43000 Kajang, Selangor, Malaysia

Tel: 603-87694470 Fax: 603-89262971 


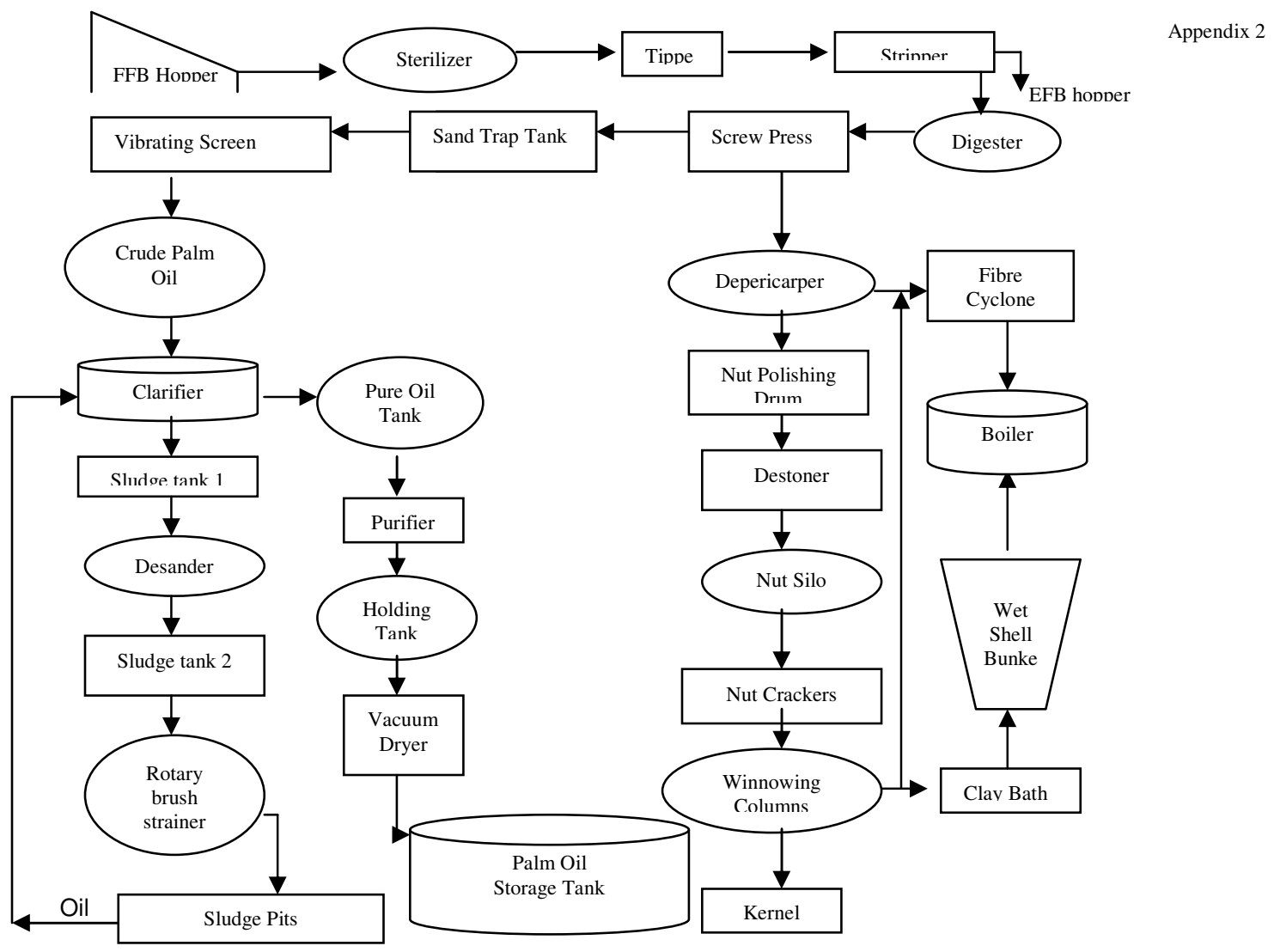

Fig. 1: Palm Oil Milling Process (System Boundary)

substantiate and defend the Malaysian oil palm industry's position with a scientific scrutiny on the environmental performance of the palm oil supply chain by conducting a Life Cycle Assessment (LCA). The concept of recycling the palm oil mill by-products is not new but merely resurfaces in the light of recent economic and environmental concern ${ }^{[1]}$. Over the years the oil palm industry has been very responsible and all the by-products have gradually been utilized. By the 1990's, the judicious utilization of the various byproducts through nutrient recycling in the fields has reduced the environmental impact paving the way towards zero-waste policy ${ }^{[1]}$. Currently there is a further move to improve the use of these by-products through the development of value-added products.

\section{OBJECTIVE}

The objective of this study is to:

- Identify the potential environmental impacts associated with the production of palm oil

- To use this assessment for evaluating opportunities to overcome the potential impacts

\section{METHODOLOGY}

Twelve palm oil mills were selected for this study. These palm oil mills were selected based on the type of mill which were either plantation based mills or private mills. They have different processing capacities of oil palm Fresh Fruit Bunch (FFB) ranging from 20 tonnes per hour up till 90 tonnes per hour. These mills are all located at different zones in west Malaysia basically from north, mid south, south and East Malaysia. Inventory data was collected from the selected palm oil mills over a period of three months from each mill which consisted of raw material usage as well as the emissions of solid, liquid and gaseous wastes as shown below:

- Raw material usage

- Excess fibre and shell mix from the boiler

- Excess shell

- Palm Oil Mill Effluent (POME)

- Emissions of flue gaseous from the boiler stack and POME ponds 
Am. J. Environ. Sci., 4 (4): 310-315, 2008

\begin{tabular}{|c|c|c|c|c|c|c|c|c|c|c|c|c|}
\hline Palm Oil Mill & 1 & 2 & 3 & 4 & 5 & 6 & 7 & 8 & 9 & 10 & 11 & 12 \\
\hline Mill Type & PL & $\mathrm{PL}$ & $\mathrm{PR}$ & $\mathrm{PR}$ & PL & PL & PL & PL & PL & $\mathrm{PL}$ & PL & $\mathrm{PR}$ \\
\hline Processing Capacity $(\mathrm{t} / \mathrm{hr})$ & 20 & 30 & 40 & 40 & 45 & 45 & 50 & 50 & 60 & 65 & 70 & 90 \\
\hline $\begin{array}{l}\text { Fuel Flow Rate (t/hr) } \\
\text { Fuel Ratio Fibre: Shell }\end{array}$ & 2.5 & 3.5 & 5.6 & 4.5 & 4.88 & 5 & 6 & 5.9 & 7.5 & 7.5 & 13 & 11 \\
\hline $\begin{array}{l}\text { Steam output }(\mathrm{t} / \mathrm{hr}) \\
\text { Environmental Inputs }\end{array}$ & 10 & 14 & 22.5 & 17.5 & 19 & 18 & 24 & 23.5 & 30 & 30.5 & 52 & 42.5 \\
\hline Fresh fruit bunch $(\mathrm{t})$ & 4.93 & 5.07 & 5.34 & 5.48 & 5.27 & 4.67 & 5.47 & 5.1 & 4.67 & 4.67 & 4.87 & 5.39 \\
\hline Power from turbine $(\mathrm{kWh})$ & 98.59 & 101.38 & 106.73 & 109.57 & 105.48 & 93.41 & 109.34 & 101.91 & 93.48 & 93.46 & 97.36 & 107.71 \\
\hline Power from Grid $(\mathrm{kWh})$ & 2 & 1.99 & 0.18 & 0.25 & 2.95 & 0 & 0 & 0 & 0 & 0 & 0 & 0.1 \\
\hline Diesel for Mill Use (L) & 2.17 & 0 & 1.29 & 1.98 & 2.92 & 2.86 & 2.45 & 2.12 & 4.47 & 3.37 & 4.51 & 0.38 \\
\hline Diesel for Vehicles in Mill (L) & 0.28 & 0.15 & 2.6 & 2.96 & 0.84 & 3.54 & 1.08 & 1.25 & 3.4 & 3.41 & 0.68 & 2.1 \\
\hline Boiler fuel : Shell (t) & 0.13 & 0.27 & 0.22 & 0.14 & 0.2 & 0.06 & 0.14 & 0.13 & 0.11 & 0.11 & 0.36 & 0.07 \\
\hline Mesocarp Fibre ( $\mathrm{t}$ ) & 0.51 & 0.63 & 0.52 & 0.57 & 0.47 & 0.58 & 0.55 & 0.52 & 0.43 & 0.43 & 0.55 & 0.6 \\
\hline Boiler water consumption $(\mathrm{t})$ & 2.5 & 3.64 & 2.92 & 2.79 & 2.66 & 2.35 & 2.88 & 2.54 & 2.1 & 2.14 & 3.64 & 2.55 \\
\hline Steam for Sterilization $(\mathrm{t})$ & 2.46 & 3.29 & 2.77 & 2.63 & 2.64 & 2.34 & 2.84 & 2.55 & 2.1 & 2.1 & 3.16 & 2.53 \\
\hline Steam to turbine ( $\mathrm{t}$ ) & 2.5 & 3.64 & 2.92 & 2.79 & 2.66 & 2.35 & 2.88 & 2.54 & 2.1 & 2.14 & 3.64 & 2.55 \\
\hline $\begin{array}{l}\text { Water consumption for process t) } \\
\text { Environmental Outputs }\end{array}$ & 3.42 & 2.95 & 3.48 & 3.79 & 3.67 & 3.26 & 3.68 & 3.57 & 3.51 & 3.47 & 3.66 & 3.38 \\
\hline Kernel $(t)$ & 0.39 & 0.41 & 0.43 & 0.44 & 0.42 & 0.37 & 0.44 & 0.41 & 0.37 & 0.37 & 0.39 & 0.43 \\
\hline Mesocarp Fibre ( $\mathrm{t}$ ) & 0.08 & 0 & 0.12 & 0.09 & 0.16 & 0 & 0.1 & 0.09 & 0.13 & 0.13 & 0.04 & 0.05 \\
\hline Shell $(\mathrm{t})$ & 0.22 & 0.09 & 0.15 & 0.24 & 0.17 & 0.26 & 0.24 & 0.23 & 0.22 & 0.22 & 0 & 0.31 \\
\hline Empty Fruit Bunch (t) & 1.13 & 1.17 & 1.23 & 1.26 & 1.21 & 1.07 & 1.26 & 1.17 & 1.08 & 1.07 & 1.12 & 1.24 \\
\hline Palm Oil Mill Effluent ( $t$ ) & 2.96 & 3.04 & 3.2 & 3.29 & 3.16 & 2.8 & 3.28 & 3.06 & 2.8 & 2.8 & 2.92 & 3.23 \\
\hline Methane form POME pond (m3) & 53.83 & 55.35 & 58.27 & 59.82 & 57.59 & 51 & 59.7 & 55.64 & 51.04 & 51.03 & 53.16 & 58.81 \\
\hline $\mathrm{CO} 2$ form POME pond (m3) & 28.99 & 29.81 & 31.38 & 32.21 & 31.01 & 27.46 & 32.15 & 29.96 & 27.48 & 27.48 & 28.62 & 31.67 \\
\hline $\begin{array}{l}\text { Boiler Ash }(\mathrm{t}) \\
\text { Flue gas from stack }\end{array}$ & 0.01 & 0.02 & 0.02 & 0.02 & 0.02 & 0.01 & 0.02 & 0.02 & 0.01 & 0.01 & 0.01 & 0.02 \\
\hline Particulate Matter (kg) & 0.07 & 0.15 & 0.11 & 0.13 & 0.14 & 0.13 & 0.15 & 0.15 & 0.16 & 0.17 & 0.45 & 0.7 \\
\hline $\mathrm{CO}(\mathrm{kg})$ & 0.02 & 0.05 & 0.06 & 0.05 & 0.06 & 0.06 & 0.06 & 0.06 & 0.07 & 0.07 & 0.14 & 0.13 \\
\hline $\mathrm{CO} 2(\mathrm{~kg})$ & 13.74 & 43.47 & 56.87 & 57.39 & 56.06 & 60.72 & 60.7 & 59.41 & 67.99 & 68.81 & 161.2 & 142.18 \\
\hline SOx $(\mathrm{kg})$ & 0.001 & 0.001 & 0.001 & 0.001 & 0.001 & 0.001 & 0.001 & 0.001 & 0.001 & 0.001 & 0.003 & 0.003 \\
\hline NOx (kg) & 0.04 & 0.08 & 0.12 & 0.1 & 0.09 & 0.11 & 0.1 & 0.09 & 0.1 & 0.1 & 0.2 & 0.25 \\
\hline EFB & Mulching & Mulching & $\begin{array}{l}\text { Shredded } \\
\text { For fuel use }\end{array}$ & Mulching & Mulching & Mulching & Mulching & Mulching & Mulching & Mulching & Mulchin & Mulching \\
\hline POME & $\begin{array}{l}\text { Treated for } \\
\text { Fertilizer } \\
\text { Use }\end{array}$ & $\begin{array}{l}\text { Treated for } \\
\text { Fertilizer } \\
\text { Use }\end{array}$ & $\begin{array}{l}\text { Treated } \\
\text { and sold } \\
\text { as Fertilizer }\end{array}$ & $\begin{array}{l}\text { Treated } \\
\text { and } \\
\text { Discharged }\end{array}$ & $\begin{array}{l}\text { Treated for } \\
\text { Fertilizer } \\
\text { use }\end{array}$ & $\begin{array}{l}\text { Treated for } \\
\text { Fertilizer } \\
\text { use }\end{array}$ & $\begin{array}{l}\text { Treated for } \\
\text { Fertilizer } \\
\text { use }\end{array}$ & $\begin{array}{l}\text { Treated for } \\
\text { Fertilizer } \\
\text { use }\end{array}$ & $\begin{array}{l}\text { Treated for } \\
\text { Fertilizer } \\
\text { use }\end{array}$ & $\begin{array}{l}\text { Treated for } \\
\text { Fertilizer } \\
\text { use }\end{array}$ & $\begin{array}{l}\text { Treated for } \\
\text { Fertilizer } \\
\text { use }\end{array}$ & $\begin{array}{l}\text { Treated For } \\
\text { Fertilizer } \\
\text { and } \\
\text { Discharged }\end{array}$ \\
\hline $\begin{array}{l}\text { Excess } \\
\text { Mesocarp Fiber } \\
\text { and Shell }\end{array}$ & $\begin{array}{l}\text { Sold as } \\
\text { fuel }\end{array}$ & $\begin{array}{l}\text { Sold as } \\
\text { fuel }\end{array}$ & $\begin{array}{l}\text { Sold as } \\
\text { fuel }\end{array}$ & $\begin{array}{l}\text { Sold as } \\
\text { fuel }\end{array}$ & $\begin{array}{l}\text { Sold as } \\
\text { fuel }\end{array}$ & $\begin{array}{l}\text { Sold as } \\
\text { fuel }\end{array}$ & $\begin{array}{l}\text { Sold as } \\
\text { fuel }\end{array}$ & $\begin{array}{l}\text { Sold as } \\
\text { fuel }\end{array}$ & $\begin{array}{l}\text { Sold as } \\
\text { fuel }\end{array}$ & $\begin{array}{l}\text { Sold as } \\
\text { fuel }\end{array}$ & $\begin{array}{l}\text { Sold as } \\
\text { fuel }\end{array}$ & $\begin{array}{l}\text { Sold as } \\
\text { fuel }\end{array}$ \\
\hline Boiler ash & $\begin{array}{l}\text { land } \\
\text { Application }\end{array}$ & $\begin{array}{l}\text { land } \\
\text { Application }\end{array}$ & $\begin{array}{l}\text { land } \\
\text { Application }\end{array}$ & $\begin{array}{l}\text { land } \\
\text { Application }\end{array}$ & $\begin{array}{l}\text { land } \\
\text { Application }\end{array}$ & $\begin{array}{l}\text { land } \\
\text { Application }\end{array}$ & $\begin{array}{l}\text { land } \\
\text { Application }\end{array}$ & $\begin{array}{l}\text { land } \\
\text { Application }\end{array}$ & $\begin{array}{l}\text { land } \\
\text { Application }\end{array}$ & $\begin{array}{l}\text { land } \\
\text { n Application }\end{array}$ & $\begin{array}{l}\text { Iand } \\
\text { Application }\end{array}$ & $\begin{array}{l}\text { land } \\
\text { Application }\end{array}$ \\
\hline
\end{tabular}

- Empty Fruit Bunch (EFB) and boiler ash

- Fuel flow rate in boiler and fuel ratio

- Energy consumption

- Recycling and treatment of wastes

The inventory data collected was calculated to quantify the inputs from the environment and outputs to the environment for every tonne of palm oil produced to create a Life Cycle Inventory (LCI). Using the LCI data for every one tonne of palm oil produced, the Life Cycle Impact Assessment (LCIA) was conducted using the Simapro Software version 6.0. The Methodology selected to conduct this LCIA is the Eco indicator 99.

System boundary and functional unit: A gate to gate study was carried out where by the system boundary was set to only include the production process of the palm oil as shown in Figure 1in Appendix 1. The starting point is at the FFB hoppers where the FFBs are received up till the production of the palm oil in the storage tanks. The functional unit for this study is one tonne of palm oil produced.

Limitations/ Constraints:he Simapro software used is an European software with European data ${ }^{[7]}$. However, the software is generic ${ }^{[7]}$ and Malaysian data has been input into the database wherever possible to conduct this study. However the background data has been adopted from the database it self for example the fertilizer energy use, diesel etc due to lack of Malaysian data in these fields. This is one of the main constrains in determining the LCIA as Malaysia lacks the much needed background data. With this constrain in mind the LCIA is conducted.

\section{RESULTS AND DISCUSSION}

Table 1 (Appendix 2) shows the LCI of the production of one tonne of palm oil. Palm oil mills numbered 3, 4 and 12 are private mills. These mills do not own oil palm plantations. They receive their FFBs from other private oil palm plantation owners. The other nine palm oil mills are all plantation based mills which have their own oil palm plantations. The environmental inputs to produce one tonne of palm oil were FFB, power consumption from turbine and grid, diesel consumption, boiler fuel, water consumption for boiler as well as process and steam input to turbine, sterilization or cooking of the fruits. The rows which have been highlighted in Table 1 are basically renewable energy and recycled materials. The outputs 


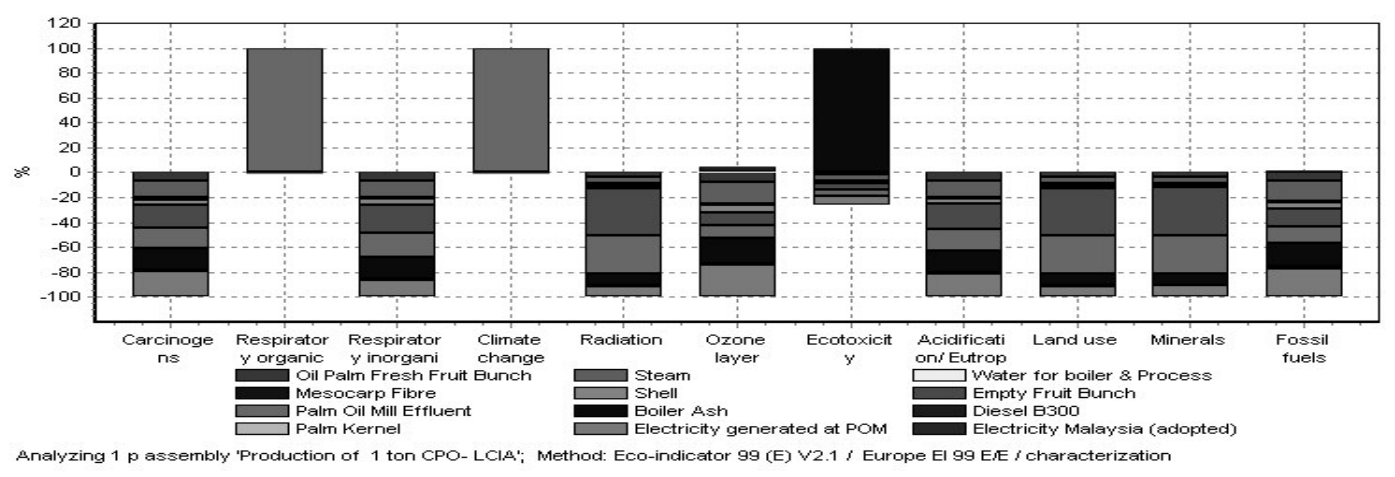

Fig. 2: Characterization of LCIA of the production of one tonne of Palm Oil (gate to gate)

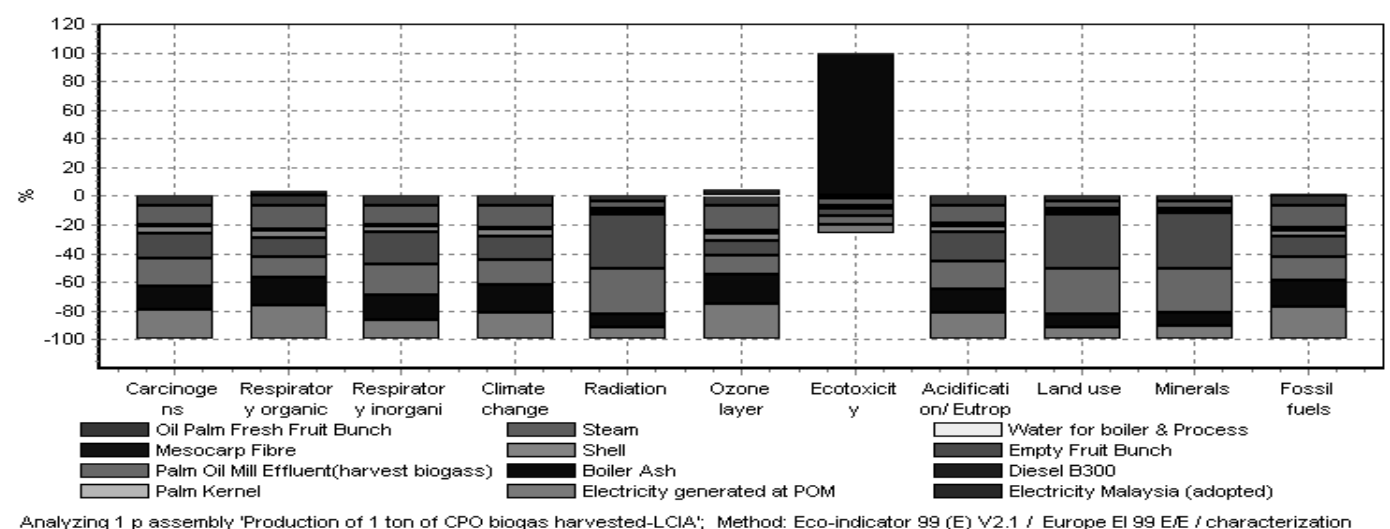

Fig. 3: Characterization of LCIA of the production of one tonne of Palm Oil (gate to gate) (Biogas harvested and used as energy)

to the environment when one tonne of palm oil is produced as shown in Table 1 is the various biomass wastes, palm oil mill effluent, gaseous emissions from the stack and biogas as well the ash from the boiler.

Figure 2 shows the characterization of the LCIA of the production of one ton of palm oil which shows that there are only two potential impacts. Figure 3 shows the characterization of the LCIA of the production of one ton of palm oil when the biogas is harvested and used as energy. Figure 4 shows the normalized value for the production of one tonne of palm oil.

Figure 2 shows the characterization of the LCIA for the production of one ton of palm oil. Based on the results most of the impact categories show savings rather than impact. The main input for turbine system processing of palm oil is electricity and this electricity is self generated in the boiler ${ }^{[3]}$. In the palm oil mills mesocarp fibre and shell are used as fuel in the boiler and are burnt to produce heat to convert water into steam. This steam is then used to run a turbine which generates electricity for the milling process and the whole mill compound. The mesocarp fibre and shell are actually wastes from the FFB which are then recycled as boiler fuel. The mesocarp fibre is the waste after oil has been pressed out of the mesocarp of the fruit. The shell is the outer layer of the nut which when cracked produces kernel and shell. Kernel will be shipped to kernel crushing plants to extract palm kernel oil while shell is a waste. However in the palm oil mills these wastes are considered very valuable by products which serve as an energy source for the mill. Due to the existence of these by-products, the palm oil mills are very self sufficient producing their own energy to operate and also to supply energy to the estates in some cases. The load to produce electricity using fossil fuel sources has been taken off from the environment and at the same time the load to treat that amount of mesocarp fibre and shell has been removed from the environment. The steam that has passed through the turbine is then stored at a back pressure receiver tank. This steam now which is at a lower pressure is used for the sterilization or cooking process. Here this steam is recycled and the load to produce steam again for this process has been 


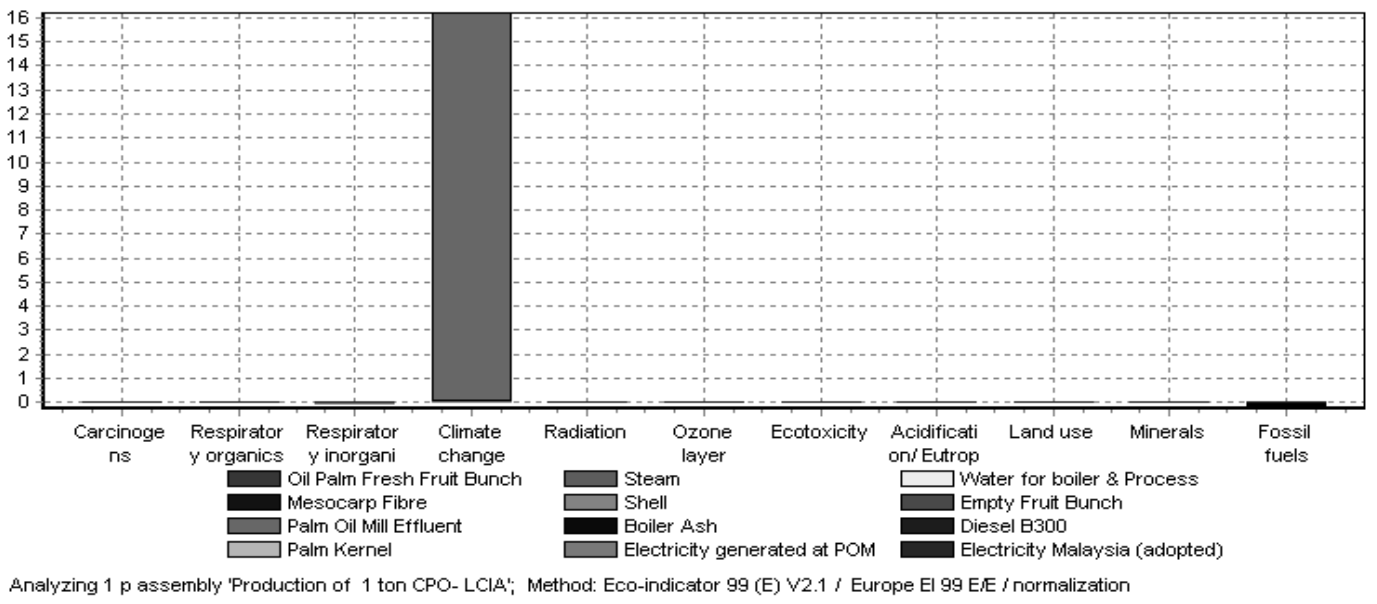

Fig. 4: Normalization of Potential Impacts

taken off from the environment. All the outputs from the mills are either recycled within the compound or at the plantations or some even sold and reused as fuel or fertilizers elsewhere as shown in Table 1. This explains the savings that is shown in Fig. 2 due to recycling and the use of renewable energy for processing.

Within this system boundary there are only two parameters that are causing the potential impacts to the environment; they are the POME followed by the boiler ash. The impact categories that the POME contributes to are under the Respiratory Organics and Climate Change. Both these impact categories are related to air emissions. The main air emission from the POME ponds during the anaerobic digestion is the biogas which consists of methane, carbon dioxide and traces of hydrogen sulfide ${ }^{[2]}$. The un-harvested biogas is a green house gas which harms the quality of the air. In order to double check, an alternate scenario was conducted to see how the impact will be if the biogas was harvested and used as energy in the palm oil mill and the results are shown in Figure 3. Figure 3 clearly shows that when the biogas is harvested, the impact from the POME is removed and POME becomes a savings to the environment due to the reuse of the treated POME as fertilizers at the plantations.

The other potential impact is the boiler ash. The boiler ash consists of clinkers and ash due to the burning of biomass namely mesocarp fibre and shell. The impact category this potential impact contributes is under eco-toxicity. The boiler ash contains minerals and also traces of metals such as $\mathrm{Al}, \mathrm{Mg}, \mathrm{Cr}$ and Fe which are emitted to the soil when the ash is administered to the ground. The disposal of this boiler ash is the cause of this potential impact. In order to compare the most significant potential impact, normalization is done as shown in Fig. 4. Normalization assists in assessing which of the potential impacts are large and which are small by placing them in relation to the impacts for an average person. When impact potentials are normalized, they are expressed in person-equivalents (PE). In figure 4 POME has a potential impact of $16 \mathrm{PE}$. When the two potential impacts are normalized it is clear that the biogas emission from the POME has a higher and more harmful impact compared to the boiler ash. Currently only a handful of palm oil mills harvest their biogas.

We may wonder why this biogas is not harvested and industry cannot be completely blamed. The reason behind this is mainly due to the lack of infrastructure to channel this excess energy. Palm oil mills have excess energy from their biomass itself and to invest in a large sum of money to harvest the biogas will mean that they will need the infrastructure to dispose or sell the harvested biogas. However it is sad to say that such demands for this kind of renewable energy is very minimal in Malaysia. Since the mills themselves do not need anymore energy this does not seem to be a viable move for them to invest large amounts of money on a harvesting system. In order to overcome this problem; it has to be seen on a wider scale involving not only the palm oil industry on its own but also the whole energy sector of Malaysia. This includes changing policies and creating infrastructures and incentives to make harvesting such valuable biogas energy worth the while for the palm oil industry. Thanks to the current shift of events and increased environmental awareness this situation is likely to change in the near future.

The other potential impact is the boiler ash. It is time the palm oil mills dispose of the boiler ash in a better manner. For now the ash is used for land 
application on the roads and ground in the plantations and mills. There are many ways to better utilize this boiler ash.

\section{CONCLUSION}

All the while environmental management was categorized more for image purposes ${ }^{[6]}$. However in recent developments of shift towards wanting a more green earth, environmental demands are becoming marketing tools ${ }^{[6]}$. It is becoming a determining factor for use of products. In view of the current shift for higher environmental demands from customers as well as the emergence of eco labels, the need for the oil palm industry to also shift with the current trend is unavoidable. This shift is very vital for the oil palm industry as it has to be sustainable and competitive to increase its long-term profitability and sustainability. The European Union along with other western countries are known for their high environmental standards. Since European Union is the second largest importer of palm oil, it is crucial that the oil palm industry is ready to meet the higher expectation of these overseas customers on the environmental performance of the industry. These environmental performance expectations can slowly begin to transform into demands in the market place and may even become a market barrier in the future ${ }^{[5]}$.

Due to the practice of recycling and use of renewable energy, most of the impact categories show savings rather than impacts within the system boundary. If the parameters causing these two potential impacts are curbed, then this will be a further plus point for the Malaysian oil palm industry which is already avoiding fossil fuel based energy and chemical use for processing.

Recommendations: The main potential impact seems to be originating from the sludge treatment ponding system which is a regulated requirement by the Department of Environment of Malaysia. The regulated levels of Biological Oxygen Demand (BOD) is 100 ppm however there are states such as Sabah and Sarawak which require BOD levels as low as $20 \mathrm{ppm}$. In order to meet these requirements the ponding anaerobic digestion system is used. The practical approach is to actually re look at this twenty years old sludge treatment system. It is time for the industry to look into other options of sludge treatment which are available and not only sticks to the historical method used. The easiest way is to use covered ponds and digestion tanks to treat the sludge and the harvested methane can be used in the boilers at the mills. Palm oil mills can also look into options of reducing their waste water by avoiding dilution which will directly reduce their effluent quantity. There are systems already available that give good separation of the oil without dilution. The boiler ash which is currently seen as a waste should be treated as a resource. Other than $\mathrm{Mg}$, $\mathrm{Cr}, \mathrm{Fe}$ and $\mathrm{Al}$ the ash has high levels of potassium, silicon also some phosphorous which are good properties as fertilizers. However efforts should be put in to remove the un wanted elements which can harm the soil. The boiler ash may also be used as additives in concrete and cement.

\section{ACKNOWLEDGEMENTS}

The authors would like to thank to the palm oil millers for allowing us to conduct the study at their mills.

\section{REFERENCES}

1. Chan K.W., 1999. Biomass Production in The Oil Palm Industry. In: Oil Palm and The Environment. Malaysian Oil Palm Growers' Council, Kuala Lumpur : 45-50

2. Man A.N., T.S. Toh and N.S.Chua, 1999. Renewable Energy From Oil Palm Industry. In: Oil Palm and The Environment. Malaysian Oil Palm Growers' Council, Kuala Lumpur: 253-259

3. Ma A.N., 2002. Carbon Credit From Palm Biomass, Biogas and Biodiesel. In: Palm Oil Engineering Bulletin,. Malaysian Palm Oil Board Selangor Malaysia, 65: 24-25

4. Mohd Basri W., 2006 Overview of Malaysian Oil Palm Industry 2006. Malaysian Palm Oil Board. Selangor,Malaysia: 1-5

5. Narayanaswamy V., J. Altham, R.V. Berkel and M. McGregor, 2002. A Primer On Environmental Life Cycle Assessment For Australian Grains. Curtin University Of Technology Australia, Perth Australia.

6. Sanchez I. G., H. Wenzel and M.S. Jorgensen, 2003. Assessing and Improving the Feasibility of LCM. Paper Presented At CIRP Seminar On Life Cycle Engineering. Denmark.

7. Sumiani Y. and H. Sune Balle, 2007. Feasibility Study of Performing a Life Cycle Assessment on Crude Palm Oil Production in Malaysia. International Journal of Life Cycle Assessment.,12. 